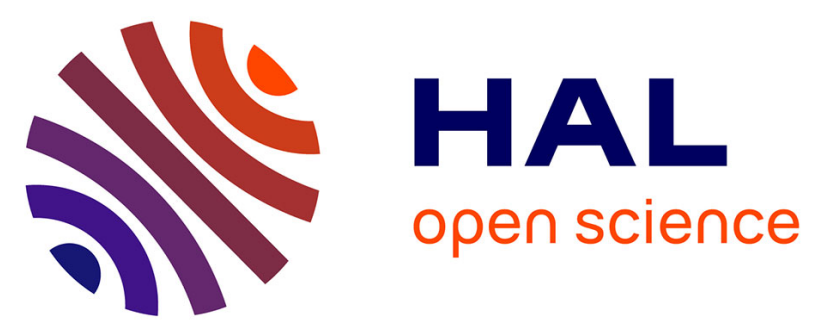

\title{
An Efficient Synthesis of Porphyrins with Different meso Substituents that Avoids Scrambling in Aqueous Media
} Agnieszka Nowak-Krol, Rémi Plamont, Gabriel Canard, J.A. Edzang, Daniel T. Gryko, Teodor Silviu Balaban

\section{- To cite this version:}

Agnieszka Nowak-Krol, Rémi Plamont, Gabriel Canard, J.A. Edzang, Daniel T. Gryko, et al.. An Efficient Synthesis of Porphyrins with Different meso Substituents that Avoids Scrambling in Aqueous Media. Chemistry - A European Journal, 2015, 21 (4), pp.1488-1498. 10.1002/chem.201403677. hal-01130057

\section{HAL Id: hal-01130057 \\ https://hal.science/hal-01130057}

Submitted on 7 Feb 2020

HAL is a multi-disciplinary open access archive for the deposit and dissemination of scientific research documents, whether they are published or not. The documents may come from teaching and research institutions in France or abroad, or from public or private research centers.
L'archive ouverte pluridisciplinaire HAL, est destinée au dépôt et à la diffusion de documents scientifiques de niveau recherche, publiés ou non, émanant des établissements d'enseignement et de recherche français ou étrangers, des laboratoires publics ou privés. 


\title{
An Efficient Synthesis of Porphyrins with Different Meso Substituents that Avoids
}

\section{Scrambling in Aqueous Media}

\author{
Agnieszka Nowak-Król, ${ }^{a, \dagger}$ Rémi Plamont, ${ }^{b, \dagger}$ Gabriel Canard, ${ }^{b, c}$ Judicaelle Andeme Edzang, \\ Daniel T. Gryko ${ }^{\mathrm{a}, *}$ and Teodor Silviu Balaban ${ }^{\mathrm{b}, *}$
}

To the memory of Alan Roy Katritzky, magister of heterocyclic chemistry

[a] Institute of Organic Chemistry of the Polish Academy of Sciences, Kasprzaka 44/52, 01-224 Warsaw, Poland E-mail: dtgryko@icho.edu.pl

[b] Aix Marseille Université, Centrale Marseille, CNRS, Institut des Sciences Moléculaires de Marseille (iSm2), UMR 7313, Chirosciences, Avenue Escadrille Normandie Niemen, St. Jerôme, F-13397 Marseille CEDEX 20, France. Fax : (+) 33413594619

E-mail: ts.balaban@univ-amu.fr

[c] Aix Marseille Université, CNRS, CINaM UMR 7325, 13288 Marseille, France

Supporting information for this article is available on the WWW under http://www.chemeurj.org/ or from the author.

\begin{abstract}
We have developed new conditions that afford regioisomerically pure trans- $\mathrm{A}_{2} \mathrm{~B}_{2}-, \mathrm{A}_{3} \mathrm{~B}-$, and trans- $\mathrm{AB}_{2} \mathrm{C}-$ porphyrins bearing aryl and arylethynyl substituents. The porphyrin formation reaction involves the acid-catalyzed condensation of dipyrromethanes with aldehydes followed by oxidation with $p$-chloranil or DDQ. Optimal conditions for condensation were identified after examining various reaction parameters such as solvent composition, acid concentration, and reaction time. The conditions identified (for aromatic aldehydes: $\mathrm{EtOH}: \mathrm{H}_{2} \mathrm{O} 4: 1,[\mathrm{DPM}]=4 \mathrm{mM}$, [aldehyde] $=4 \mathrm{mM}$, $[\mathrm{HCl}]=$ $48 \mathrm{mM}, 16 \mathrm{~h}$ and for arylethynylaldehydes: THF: $\mathrm{H}_{2} \mathrm{O} 2: 1,[\mathrm{DPM}]=13 \mathrm{mM}$, [aldehyde] $=13 \mathrm{mM},[\mathrm{HCl}]=0.15 \mathrm{M}, 3 \mathrm{~h}$ ) resulted in formation of porphyrins in yields of $9-38 \%$ without detectable scrambling. This synthesis is compatible with diverse functionalities such as ester, or nitrile. In total 20 new trans- $\mathrm{A}_{2} \mathrm{~B}_{2^{-}}, \mathrm{A}_{3} \mathrm{~B}-$, and trans- $\mathrm{AB}_{2} \mathrm{C}-$ porphyrins were prepared. The scope and limitations of two sets of reaction conditions have been explored. The methodological advantage of this approach is its straightforward access to building blocks and the formation of the porphyrin core in higher yields than by any other methodology and by using environmentally benign and non-hazardous chemicals.
\end{abstract}

Keywords: porphyrinoids $\bullet$ (non)scrambling porphyrins $\bullet$ green chemistry $\bullet \pi$-extension $\bullet$ synthesis

\section{Introduction}

The seminal discovery by Jonathan S. Lindsey and his coworkers of a versatile synthetic method for meso-tetraarylporphyrins under very mild conditions ${ }^{[1]}$ has led to variations that have been widely adopted and have served as an entry of porphyrinoids into functional materials with applications ranging from medicinal chemistry and photodynamic therapy to molecular electronics. ${ }^{[2]}$ Because this methodology tolerates a variety of functional groups, this procedure has allowed the design of novel systems in which the $\mathrm{A}_{4}$-porphyrins are first formed and then subsequently modified by substitution reactions or functional group manipulations, leading to the desired target functional molecules in acceptable yields. ${ }^{[3]}$ Prior to the Lindsey method, elaborate synthetic transformations were conducted to afford usually aldehydes, ${ }^{[4]}$ which were then submitted to the classical Adler-Longo, ${ }^{[5]}$ Rothemund, ${ }^{[6]}$ or McDonald ${ }^{[7]}$ condensations with pyrrole or its derivatives under harsh conditions, such as heating to reflux in propionic acid under aerobic conditions. As this last porphyrin-forming step proceeds with only low to modest yields, this synthetic strategy was not atom economical, as defined by Trost, ${ }^{[8]}$ and failed completely with functional groups sensitive to high temperatures, acidic conditions, and oxygen.

Thus, the synthesis of meso-substituted $\mathrm{A}_{4}$ porphyrins is in its mature state. However, if substrates containing two to four pyrrole units, such as dipyrromethanes or bilanes, ${ }^{[9]}$ were subjected to the usual mild Lindsey conditions, small amounts of isomeric porphyrins were formed as by-products due to the so-called scrambling of the porphyrinogen. In acidic medium, the ring of this cyclic tetrapyrrole can open and then reform, thereby leading to interchange of neighboring pyrrole rings. Lindsey and co-workers optimized conditions for the [2+2] condensation between sterically unhindered dipyrromethanes and aldehydes leading to trans- $\mathrm{A}_{2} \mathrm{~B}_{2}$-porphyrins. ${ }^{[10]}$ The very gentle conditions (condensation at $10 \mathrm{mM}$ in $\mathrm{MeCN}$ at $0{ }^{\circ} \mathrm{C}$ with $\mathrm{BF}_{3} \cdot \mathrm{Et}_{2} \mathrm{O}$ catalysis in the presence of $\mathrm{NH}_{4} \mathrm{Cl}$ followed by DDQ oxidation) made it possible to avoid scrambling but the yields of the desired trans- $\mathrm{A}_{2} \mathrm{~B}_{2}$-porphyrins were in the range of only $5-10 \%$. While many modifications ${ }^{[11]}$ and significant progress ${ }^{[12]}$ have been achieved for the synthesis of $\mathrm{A}_{4}$-porphyrins, few improvements were made for trans- $\mathrm{A}_{2} \mathrm{~B}_{2}$-porphyrins. ${ }^{[13]}$ 
Due to scrambling, the isolation of the desired porphyrin from its closely related regioisomers by chromatographic separation is both tedious and low-yielding. Unsubstituted dipyrromethane, ${ }^{[14]}$ sterically-hindered dipyrromethanes, and dipyrromethanes with electron-withdrawing groups are somewhat more resistant to scrambling than simple dipyrromethanes. ${ }^{[15]}$

A preparatively useful method for synthesizing variously substituted porphyrins under mild conditions that avoids scrambling has been a long sought reaction for the past two decades. Lindsey and co-workers proposed a few interesting solutions, which work on a reasonable scale, including a tin-complexation strategy in the preparation of 1,9-diacyldipyrromethanes or the direct synthesis of palladium trans- $\mathrm{A}_{2} \mathrm{~B}_{2}-$ porphyrins from acyldipyrromethanes. ${ }^{[16]}$ Senge has addressed this problem and has elegantly solved it by using organolithium reagents that efficiently lithiate any meso-free position which then can be substituted, followed by an oxidative step in an overall $\mathrm{S}_{\mathrm{NAr}}-$ type reaction. ${ }^{[17]}$ Such sequential substitutions have proven viable for obtaining even ABCD-type porphyrins starting from the unsubstituted porphine, or $\mathrm{A}_{2} \mathrm{BC}$-type starting from 5,15-disubstituted porphyrins. ${ }^{[18]}$

Herein, we report an alternative novel and "greener" method which avoids the use of rather hazardous reagents and proceeds in aqueous media. This method has been discovered simultaneously in two different laboratories, one in Marseille and the other in Warsaw. ${ }^{[19]}$ Although different porphyrins were targeted and slightly different reaction conditions were explored, it is clear that the same basic reaction was involved. Therefore, in the interest of the readers, we are now jointly publishing our results.

While attempting the synthesis of a corrole devoid of the 5 and 15 meso-substituents, the group in Marseille serendipitously found that an attempted reaction following the initial "Gryko" conditions, ${ }^{[20]}$ functioned completely differently, yielding no corrole(s), but only the trans- $\mathrm{A}_{2}$-porphyrin. However, it has not escaped our attention that no scrambling had occurred. Subsequent work explored the scope and robustness of this synthetic procedure, which clearly showed that a major problem in porphyrin syntheses could be circumvented.

The group in Warsaw targeted meso-arylethynylporphyrins, compounds which have received considerable attention in the field of materials chemistry due to their potential application in optoelectronic devices. ${ }^{[21]}$ These molecules have emerged as promising candidates for optical limiters, ${ }^{[22]}$ two-photon absorption (2PA) sensitizers for near infrared (NIR) photorefractive composites, ${ }^{[12 a]}$ reverse saturable absorbers, ${ }^{[23]}$ materials for second harmonic generation, ${ }^{[1 \mathrm{~g}]}$ and for dye-sensitized solar cells (DSSCs). ${ }^{[24]}$ Arylethynylporphyrins have a significantly altered electronic structure. Incorporation of two ethynyl moieties elongates the $\pi$-conjugation pathway and improves the electronic interactions between the phenyl substituents and the porphyrin core owing to the rigid two-dimensional structures, which results in enhancement of 2PA values ${ }^{[2,25]}$ and bathochromatically shifted absorption. ${ }^{[1 \mathrm{~b}, 3,26]}$ They also display large first-order hyperpolarizabilities ${ }^{[11 \mathrm{~g}, 27]}$ and high thermal stability. ${ }^{[1 \mathrm{~g}]}$

Although meso-arylethynyl trans- $\mathrm{A}_{2} \mathrm{~B}_{2}$-porphyrins are typically synthesized via preparation of trans- $\mathrm{A}_{2}$-porphyrins unsubstituted at two meso-positions, followed by bromination and Sonogashira coupling, ${ }^{[1 \mathrm{~g}, 2,5 \mathrm{a}, 28,29]}$ a second approach starting from phenylpropargyl aldehydes has also been explored. ${ }^{[30-32]}$ The reaction outcomes were, however, very sensitive to the applied conditions and the target porphyrins were often accompanied by undesired rearrangement products due to unavoidable scrambling. ${ }^{[33]}$

\section{Results and Discussion}

\section{Tetraarylporphyrins}

Gryko and co-workers described the synthesis of trans- $\mathrm{A}_{2} \mathrm{~B}$-corroles with high yields and without any scrambling. ${ }^{[20 \mathrm{c}]}$ This procedure wss based on the synthesis of meso-triarylbilanes in a water/methanol mixture in which a precipitation occurs before scrambling can take place. We thought that this method would produce the corresponding trans $-\mathrm{A}_{2} \mathrm{~B}_{2}$-porphyrin if the dipyrromethane/aldehyde ratio was changed from $2 / 1$ to $1 / 1$. The dipyrromethane concentration was also decreased twice in order to prevent the bilane from precipitating and therefore to allow the formation of the required porphyrinogen. We chose the reaction between $p$-tolualdehyde (3) and the simple unsubstituted dipyrromethane 1 leading to 5,15-di-p-tolylporphyrin (5) as a model system (Scheme 1). After one hour, the reaction mixture was extracted by $\mathrm{CHCl}_{3}$ and oxidized by $p$-chloranil.

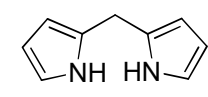

$+\mathrm{RCHO}$

2. $\mathrm{R}=3,5-(t-\mathrm{Bu}) \mathrm{C}_{6} \mathrm{H}_{3}$ 3. $\mathrm{R}=4-\mathrm{MeC}_{6} \mathrm{H}_{4}$

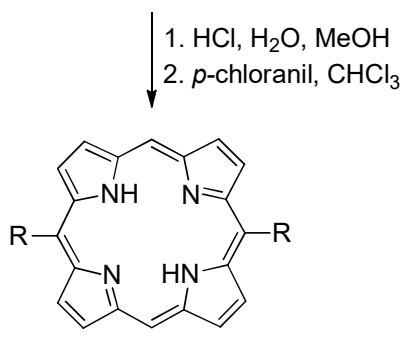

4. $\mathrm{R}=3,5-(t-\mathrm{Bu}) \mathrm{C}_{6} \mathrm{H}_{3} \quad 4 \%$

5. $\mathrm{R}=4-\mathrm{MeC}_{6} \mathrm{H}_{4} \quad 36 \%$

Scheme 1. First attempts to synthesize trans- $\mathrm{A}_{2}$-porphyrins. 
This reaction resulted in the formation of porphyrin $\mathbf{5}$ in $36 \%$ yield and without any detectable scrambling. Encouraged by this result, we tried to apply the same conditions for the more lipophilic 3,5-di-tert-butylbenzaldehyde 2 . Unfortunately, in this case the yield of porphyrin 4 was only of $4 \%$ (Scheme 1). Despite this small yield, the lack of scrambling prompted us to optimize the experimental parameters of this reaction.

The low solubility of 3,5-di-tert-butylbenzaldehyde in a polar medium and the possible precipitation of the bilane seemed to account for the low yield. Consequently, we examined the solubility of this aldehyde in polar solvents and we observed that the solubility was comparable in $\mathrm{MeOH}$ and $\mathrm{EtOH}$ for this aldehyde, but the reaction intermediates were more soluble in the latter alcohol. Since EtOH is the more "greener" solvent and of course fully miscible with water, we focused on this solvent in further attempts. The volume of water was a crucial parameter because the more water is added, the lower will be the solubility of the organic intermediates. Nevertheless, a sufficient amount of water is required in order to dilute the $\mathrm{HCl}$, thus preventing scrambling side-reactions. With this scope, the aldehyde concentration was slightly reduced from $5 \mathrm{mmol} / \mathrm{L}$ to $4 \mathrm{mmol} / \mathrm{L}$ while the ethanol/water ratio was raised from $1 / 1$ to $4 / 1$ and the acid concentration was lowered from $30 \mathrm{mmol} / \mathrm{L}$ to $24 \mathrm{mmol} / \mathrm{L}$ (Table 1 , Entry 1 ).

This first modification proved to be important because the yield of porphyrin 4 increased from $4 \%$ to $20 \%$. An increase of the dipyrromethane concentration to $6 \mathrm{mmol} / \mathrm{L}$ (Entry 2) lowered the yield (12\%) so the former concentration was kept constant in further trials. The polarity of the reaction medium was then lowered by decreasing the amount of $\mathrm{HCl}$ in the reaction (Entry 3). Since a lower catalyst concentration gave a lower yield (10\%), we conducted the reaction for a longer time of $16 \mathrm{~h}$ (Entry 4 ), obtaining the expected compound with a yield of $30 \%$. Extending the reaction time to $168 \mathrm{~h}$ (Entry 5), astonishingly decreased the yield to $15 \%$ probably due to other unexplored side-reactions. Thus the $16 \mathrm{~h}$ reaction time at the Marseille summer room temperature $\left(\sim 25{ }^{\circ} \mathrm{C}\right)$ seemed optimal. When we changed the ratio of $\mathrm{EtOH} / \mathrm{H}_{2} \mathrm{O}$ in an effort to boost yield by improving solubility (Entry 6) the yield of porphyrin 4 decreased to $25 \%$. We performed the same procedure as in entry 4 with a two-fold increase in reactant concentration (Entry 7), but again observed a lowered yield (9\%). Thus the optimum experimental conditions for the porphyrinogen formation were then fixed according to Entry 4.

We also explored the preparative robustness using "greener" reaction conditions (Table 1, Entries 8-10). To simplify the oxidation step, we introduced the oxidant ( $p$-chloranil) directly in the ethanol/water mixture after neutralizing the acid with a stoichiometric amount of $\mathrm{NaOH}$ (Entry 8 ). The yield was only $12 \%$ but no scrambling occurred. We performed the same procedure, but omitted $p$-chloranil and left the reaction exposed to air while heating the reaction mixture at reflux overnight; the yield was the same and again no scrambling was detected (Entry 9). On the other hand, if the acid catalyst was not neutralized, boiling the reaction mixture in air produced a significant amount of scrambling together with a lower yield (Entry 10). Even if in Entries 8 and 9, the yield is lower than in Entry 4, we obtained a nonscrambling reaction without using a rather expensive oxidant such as $p$-chloranil, without using a halogenated solvent like dichloromethane or chloroform, and with only a simple chromatographic plug to purify the porphyrin. Despite the use of this plug, all the other steps are totally in the spirit of a green chemistry approach with environmentally benign conditions. In all cases, possible scrambling was investigated by both TLC and ESI-MS of the crude reaction mixture.

Having in hand the optimized conditions, $\left(\mathrm{EtOH}: \mathrm{H}_{2} \mathrm{O}=4: 1\right.$, [DPM] $=4 \mathrm{mM}$, [aldehyde] $=4 \mathrm{mM},[\mathrm{HCl}]=48 \mathrm{mM}, 16 \mathrm{~h}$ at r.t.) we then studied the scope and limitations of this procedure (Table 2). We performed the reactions with other aromatic aldehydes as well as with an aliphatic one, obtaining in all cases trans- $\mathrm{A}_{2} \mathrm{~B}_{2}$-porphyrins $\mathbf{5}$ and 9-11 in moderate to good yields. The scrambling level was zero, according to Lindsey's classification. ${ }^{[10]}$

Subsequently, we extended this procedure to obtain $\mathrm{A}_{3} \mathrm{~B}$-type and $\mathrm{AB}_{2} \mathrm{C}$-type porphyrins. We kept the same dilution conditions as in Table 1, Entry 4 and took into consideration the formation of an intermediate bilane. For these studies, we added $0.5 \mathrm{mmol}$ of bilane and 0.5 mmol of aldehyde to $200 \mathrm{~mL}$ of EtOH and kept the same conditions as in Entry 4 for the rest of the reaction time. In the first attempted reactions for $\mathrm{A}_{3} \mathrm{~B}$-pophyrins synthesis, we did not purify the precursor (i.e., bilane). Subsequently, we undertook this purification and we obtained higher yields although this resulted in a two-step procedure. Even if this bilane purification gave better yields, the results without purification could be interesting in a greener chemistry approach and a facile synthesis more prone to be scaled up. The yields trans- $\mathrm{A}_{2} \mathrm{~B}_{2}-$ porphyrins were slightly higher if dipyrromethanes possessing electron-donating groups were employed (Table 3). In Table 4 we list the $\mathrm{AB}_{2} \mathrm{C}$ porphyrins which could be obtained via a similar two step procedure and which are all novel compounds, difficult to access by other methodologies.

\section{Arylethynylporphyrins}

In the course of our ongoing research in Warsaw on the issue of scrambling in the synthesis of trans- $\mathrm{A}_{2} \mathrm{~B}_{2}$-bis(arylethynyl)porphyrins, we previously identified two sets of conditions for lipophilic and more polar building blocks. ${ }^{[33]}$ However, these methods did not suppress scrambling to the zero level according to Lindsey's classification. ${ }^{[10]}$ Therefore, we decided to take advantage of the efficient non-scrambling method for the corrole synthesis discovered in our group. ${ }^{[20 \mathrm{c}]}$ We focused on porphyrins possessing arylethynyl substituents at two meso positions. In the initial stage of research we have verified this concept by synthesizing the series of variously substituted trans- $\mathrm{A}_{2} \mathrm{~B}_{2}-$ bis(arylethynyl)porphyrins and trans- $\mathrm{A}_{2} \mathrm{~B}_{2}$-arylporphyrins. The synthesis of the corresponding porphyrins was performed by changing the key parameters such as the volume ratio of $\mathrm{H}_{2} \mathrm{O}$ to the organic solvent, concentration of reagents, type of the organic solvent, concentration of acid, and time of the reaction (Table 5). In our preliminary studies we also tested two structurally similar oxidants: $p$-chloranil (the reaction mixture was heated under reflux) and DDQ. The latter is recognized to be inferior in corrole chemistry because as a stronger oxidant, it decreases yields of the less stable corroles. In the case of porphyrins, we did not observe any significant differences in the outcome of the reactions for these two oxidants. Therefore, in all subsequent experiments we used exclusively the more effective DDQ although it is slightly more expensive. An initial survey identified the organic solvent to water volume ratio as a critical parameter. Our first steps were directed towards $\mathrm{MeOH}$ since this solvent has proven to be the most effective in the synthesis of trans- $\mathrm{A}_{2} \mathrm{~B}$-corroles. Indeed, increasing the $\mathrm{MeOH} / \mathrm{H}_{2} \mathrm{O}$ ratio from $1: 1$ to $3: 1$ allowed us to obtain for the first time the trans- $\mathrm{A}_{2} \mathrm{~B}_{2}$-porphyrin $\mathbf{3 4}$ in a respectable $20 \%$ yield with no 
detectable scrambling. We observed a similar trend for some arylporphyrins, although it was clear that this type of porphyrins will require a separate investigation. It is also worth noting that the optimal ratio of water to organic solvent may vary for different solvents, e.g., porphyrin $\mathbf{2 8}$ was obtained in satisfactory yield when the THF-water ratio was only 2:1.

For further optimization, we selected the reaction between aldehyde $\mathbf{2 7}$ with dipyrromethane $\mathbf{2 6}$, leading to porphyrin $\mathbf{2 8}$, which can be easily purified, as a key model reaction (Table 5). The replacement of $\mathrm{MeOH}$ with $i$-PrOH proved to be beneficial (Table 5, Entries 1 and 2) by doubling the yields of the required product, while the use of $\mathrm{CH}_{3} \mathrm{CN}$ further improved the yield (Table 5, Entry 3). Notably, the reactions carried out in a THF-based system gave better outcomes than those performed in an alcohol-water or $\mathrm{CH}_{3} \mathrm{CN}$-water system. Experiments conducted with varying concentrations of acid in water and THF demonstrated that the amount of acid added to the reaction medium is a key parameter for directing the product yield. This parameter is at the crux of optimizations performed both in Warsaw and Marseille for theses porphyrin syntheses. Notably, an increase of the acid concentration had a detrimental effect (as depicted in Fig. S1). The acid concentration, which assures a satisfactory yield of porphyrin $\mathbf{2 8}$, is much lower in these studies than the optimal concentration determined for the synthesis of trans- $\mathrm{A}_{2} \mathrm{~B}$-corroles.

In summary, these studies indicate that parameters of acid concentration, substrates concentration, and molar ratio of $\mathrm{HCl}$ to substrates are interrelated. For example, in the series of reactions 19-21 the best results (Table 5, Entry 20) were obtained when both the excess of acid and acid concentration exceeded that in the best experiment (Table 5, Entry 8). The series of reactions 8-14 were thus conducted at higher dilution. On the other hand, the reactions performed at the same concentrations of acid (Table 5, Entries 10 and 18) but at different dilution, and thereby different excess of acid with respect to substrates gave relatively similar results with a slight favor of the reaction performed with a greater excess of acid (Table 5, Entry 18). The gradual increase in the percentage of THF from 33\% to 80\% (Table 5, Entries 10,15 , and 16) resulted in a systematic, though slight increase in the yields of porphyrin $\mathbf{2 8}$, confirming that the composition of the reaction medium affected the course of the reaction. The control reaction conducted in pure THF led to a very small yield of porphyrin $\mathbf{2 8}$ accompanied by the products of polycondensation and thereby verified the need to use a substantial amount of water in this method. The duration of the first acidcatalyzed step also plays an important role - prolongation of the reaction from 3 to $4.5 \mathrm{~h}$ led to a decrease in yield from $24 \%$ to $17 \%$ (Table 5 , Entries 16 and 22). However, the time of the first step cannot be too short, especially for less reactive partners. It is noteworthy that in all cases, excepting Entry 17 (Table 5), TLC and/or ESI-MS analysis revealed no scrambling. Eventually, based on the above studies, the most efficient conditions were chosen (Table 5, Entry 8, THF: $\mathrm{H}_{2} \mathrm{O} 2: 1,[\mathrm{DPM}]=13 \mathrm{mM}$, [aldehyde] $=13 \mathrm{mM},[\mathrm{HCl}]=0.15 \mathrm{M}, 3 \mathrm{~h}$ at r.t.) to investigate the scope and limitations of this methodology.

Since the aim of our investigation was to develop broadly applicable conditions for the preparation of meso-arylethynyl porphyrins, we designed four substituted derivatives 30-33 (Table 6) in addition to the 4-nitrophenylpropynal (27). Three of the phenylpropargyl aldehydes possessed electron-withdrawing substituents $\left(\mathrm{CN}, \mathrm{CF}_{3}, \mathrm{NO}_{2}\right)$ while the other two contained electron-donating substituents $(\mathrm{OMe}$, thien-2-yl). These arylpropargyl aldehydes were subsequently reacted with two dipyrromethanes (both hindered and unhindered) affording trans- $\mathrm{A}_{2} \mathrm{~B}_{2}$ porphyrins 34-37 in satisfactory yields of 9-14\% (Table 6). In the case of aldehyde 32, the first step was performed at a higher dilution using a higher concentration of acid due to the deactivating character of the electron-donating OMe group. To our delight, in all the reactions no scrambled porphyrinoid products were observed. Moreover, not only does this method suppress the formation of acid-catalyzed ring-rearrangement products, but it also limits the formation of other oligocondensates considerably simplifying the purification steps of the desired molecules. Furthermore, these data indicate that through careful control of the solubility of reactants and intermediates, as well as optimization of other parameters, it is possible to control the course of the reactions aimed at the synthesis of the desired porphyrin. We also attempted to synthesize trans $-\mathrm{A}_{2} \mathrm{~B}_{2}$-porphyrins from the building blocks with unfavorably placed substituents: aryldipyrromethanes bearing electron-withdrawing substituents and phenylpropargyl aldehydes possessing electron-donating groups. All the attempts furnished target porphyrins in yields of ca. $1 \%$, which led us to the conclusion that the crucial role in this reaction is played by the electron density of dipyrromethanes. Nevertheless, in these reactions TLC analysis showed no products of scrambling.

Encouraged by these results, we applied the novel conditions to the preparation of trans- $\mathrm{AB}_{2} \mathrm{C}$-porphyrins and $\mathrm{A}_{3} \mathrm{~B}$-porphyrins bearing one arylethynyl unit. The synthesis of these molecules by any method available to date is extremely demanding. The method presented by Lindsey ${ }^{[34]}$ is multi-step and requires the use of reactive dipyrromethane-dicarbinols. Another method involves the synthesis of $\mathrm{A}_{2}$-porphyrins and their subsequent coupling with organolithium compounds under conditions developed by Senge ${ }^{[17 a, 35]}$ to yield triarylporphyrin, followed by bromination and consecutive Sonogashira coupling with an alkyne partner. This method is limited by the availability of the organolithium reagents and the requirement for stringent anhydrous conditions. On the other hand, mixed condensation manifests itself by low yields and tedious isolation of the desired compound from the complex mixture.

We decided to explore a more facile process by using bilanes in the synthesis of porphyrins possessing one arylethynyl unit. The reaction involved condensation of this compound with arylpropargyl aldehyde leading to the corresponding porphyrinogen, which upon oxidation was converted to the desired porphyrin. For these studies we transferred the conditions developed for trans- $\mathrm{A}_{2} \mathrm{~B}_{2}-$ bis(arylethynyl)porphyrins with slight modifications. The reaction of bilane $\mathbf{4 2}$ with aldehyde $\mathbf{2 7}$ carried out in a THF-water medium for $1 \mathrm{~h}$ furnished porphyrin 46 in 18\% yield. A significant amount of 10-(4-cyanophenyl)-5,15-dimesitylcorrole (19\% yield) indicated that the time of the first step was insufficient so that the conversion of bilane was too low and during oxidation by DDQ in the second step, the unreacted bilane underwent cyclization to corrole. Prolongation of the reaction time to $2.5 \mathrm{~h}$, an increase in the percentage of THF from $67 \%$ to $75 \%$ (in order to increase the solubility of bilane) as well as an increase in the excess of aldehyde from 1.2 eq. to 2.4 eq. gave rise to the target compound 46 in 38\% (Table 7, Entry 1) yield and the conversion of bilane was complete.

The success of the synthesis of corroles in a MeOH-water system lies in the precipitation of bilane from this mixture, which prevents its further condensation. To simplify the developed procedure, we took into account the use of the crude bilane from the reaction in $\mathrm{MeOH}$-water. The precipitate was filtered and submitted to the reaction with aldehyde. Subsequent oxidation with DDQ resulted in the 
formation of a complex mixture, of which one of the components was a corrole, while another one was the target porphyrin. These results indicate that purity of the bilane and a suitable ratio of aldehyde to bilane are important.

The scope and limitation of this method were investigated under the following conditions of the first step: THF : $\mathrm{H}_{2} \mathrm{O}=3: 1$, [bilane] $=13 \mathrm{mM}$, [aldehyde $]=31 \mathrm{mM},[\mathrm{HCl}]=0.15 \mathrm{M}, 2.5 \mathrm{~h}$ at RT. For the purpose of these studies we have synthesized a set of bilanes with a wide range of substituents. It included three $\mathrm{A}_{2} \mathrm{~B}$-bilanes 42-44 and two $\mathrm{A}_{3}$-bilanes $\mathbf{5 2}$ and $\mathbf{5 3}$ - one with electron-withdrawing and another one with electron-donating substituents. As their counterparts, we used phenylpropargyl aldehydes 27, 30, and 33 possessing electron-withdrawing substituents $\left(\mathrm{CN}, \mathrm{CF}_{3}, \mathrm{NO}_{2}\right)$ and aldehydes 31, 32, and 45 with electron-donating substituents $(\mathrm{OMe}$, Me, thien-2-yl). The reaction in a THF-water system afforded a set of $\mathrm{A}_{2} \mathrm{~B}$ - and $\mathrm{A}_{3} \mathrm{~B}$-porphyrins 46- 51 and 54-56 in good to excellent yields (Tables 7 and 8 ). Moreover, the reactions were clean and the purification was straightforward. In some cases trace amounts of corroles were observed.

The optical properties of these porphyrins are analogous to other arylethynyl- and bis(arylethynyl)porphyrins synthesized previously. ${ }^{[36]}$ The introduction of phenylethynyl moiety results in a red-shift of the absorption maxima of 48 comparing to tetrakis[3,4,5tris(decyloxy)phenyl]porphyrin ${ }^{[37]}$ (Figure 1). This change is even more pronounced for bis(arylethynyl)porphyrins, e.g. 35. The shift of absorption bands corresponds to the reduction in the HOMO-LUMO gap, which in turn indicates the effective overlap of the extended $\pi$ systems between the porphyrin and aryl moieties.

Figure 1. Absorption spectra of tetrakis[3,4,5-tris(decyloxy)phenyl]porphyrin, arylethynylporphyrin 48, and bis(arylethynylporphyrin $\mathbf{3 5}$.

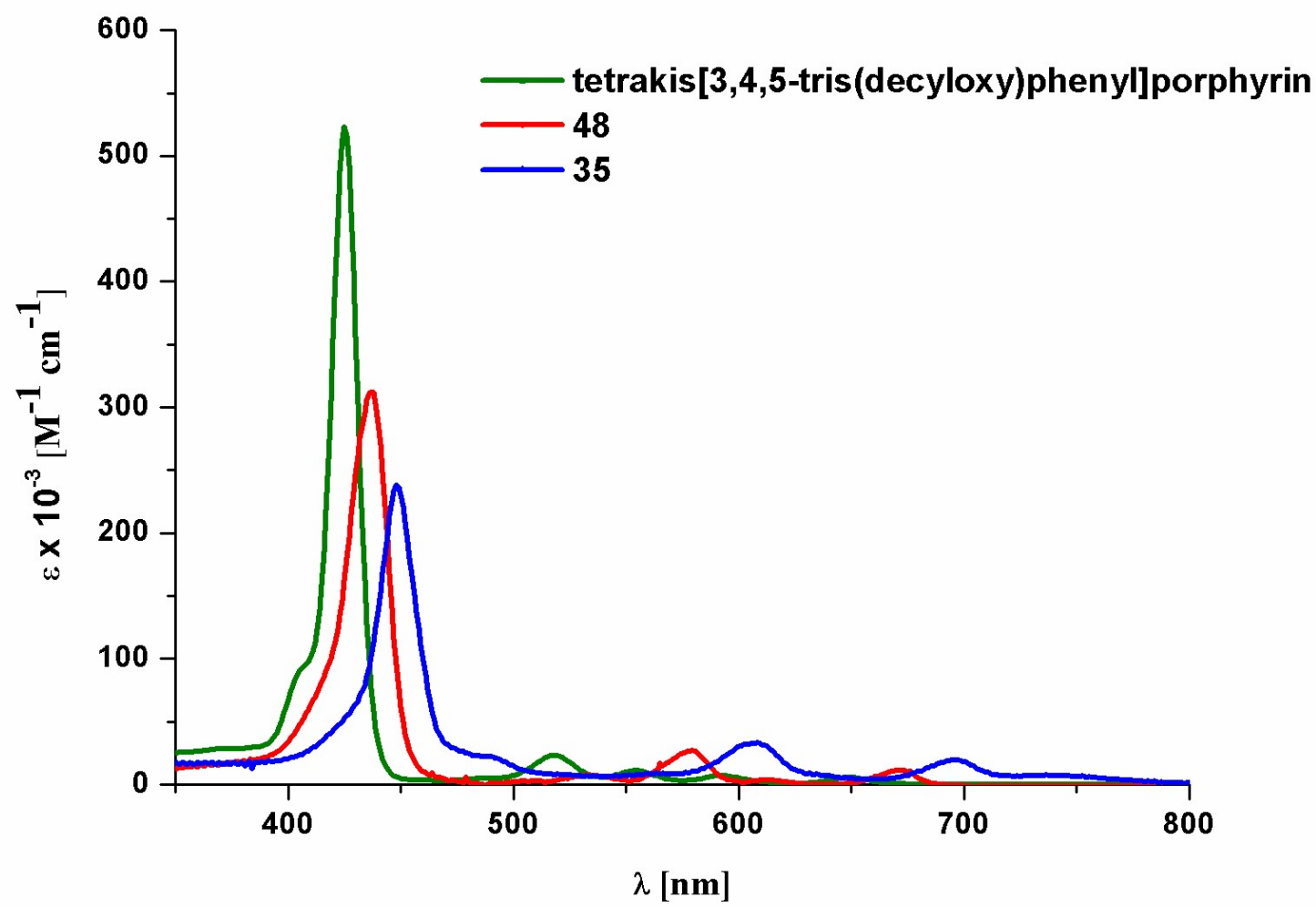




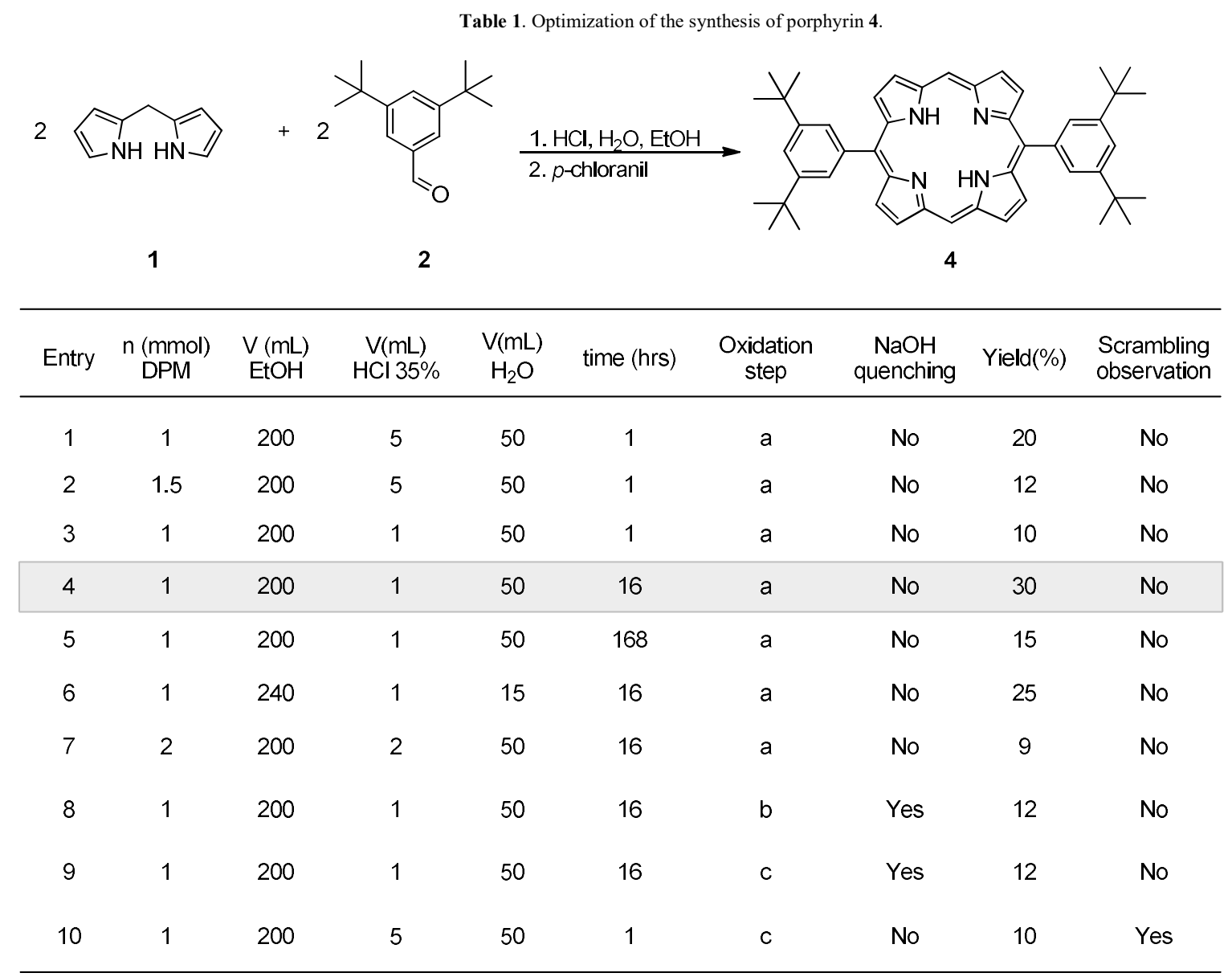

Oxidation step: (a) $p$-chloranil in $\mathrm{CHCl}_{3}$; (b) $p$-chloranil in $\mathrm{EtOH} / \mathrm{H}_{2} \mathrm{O}$; (c) air in $\mathrm{EtOH} / \mathrm{H}_{2} \mathrm{O}$.

The optimal reaction conditions were identified for Entry 4, highlighted on a grey background. 
Table 2. Isolated yields of trans- $\mathrm{A}_{2} \mathrm{~B}_{2}$-porphyrins formed under optimized $\mathrm{H}_{2} \mathrm{O} / \mathrm{EtOH}$ conditions.

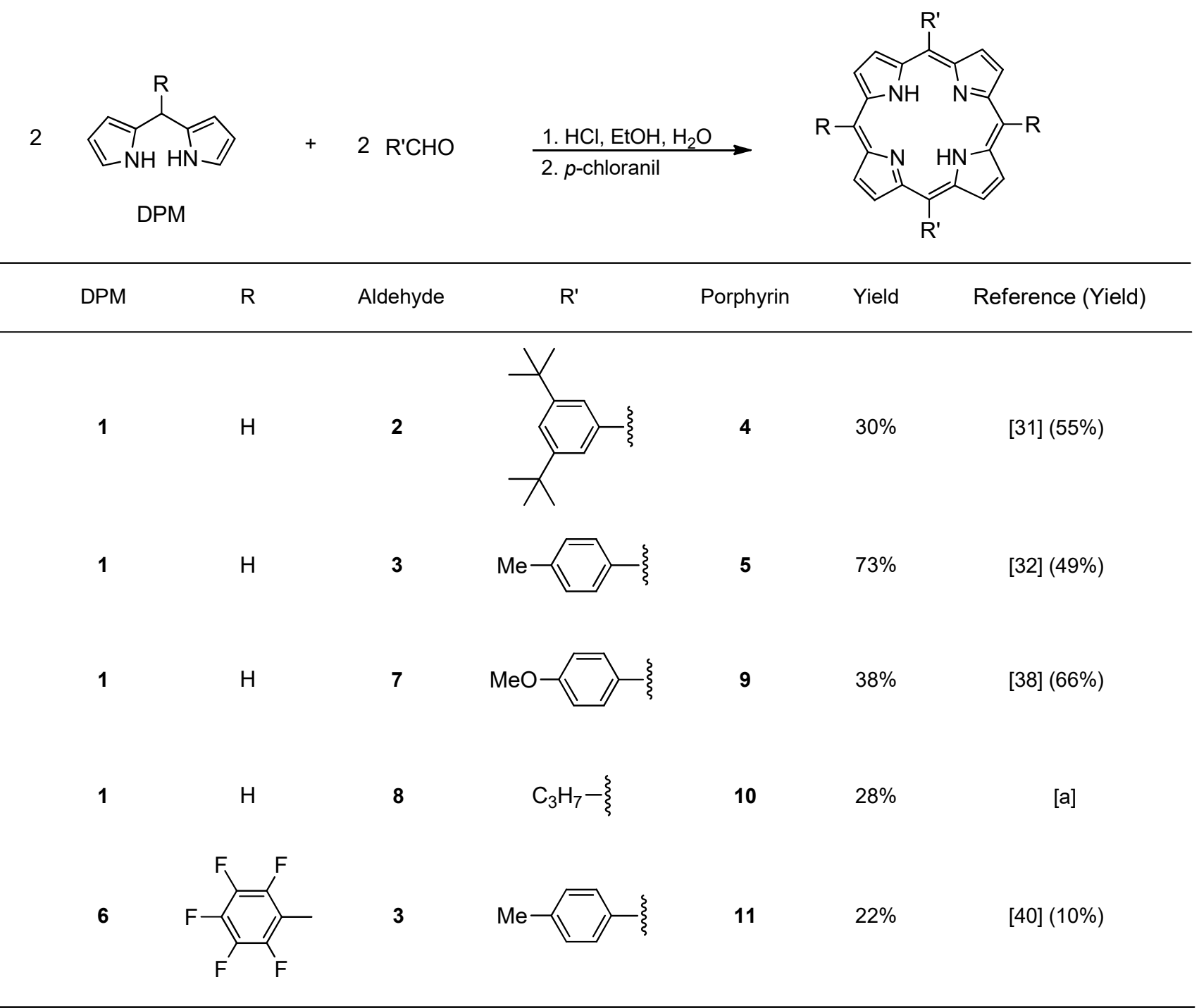

[a] present work, as from a previous patent, the yield could not be inferred. ${ }^{[39]}$ 
Table 3. Extension to the syntheses of $A_{3} B$ porphyrins.

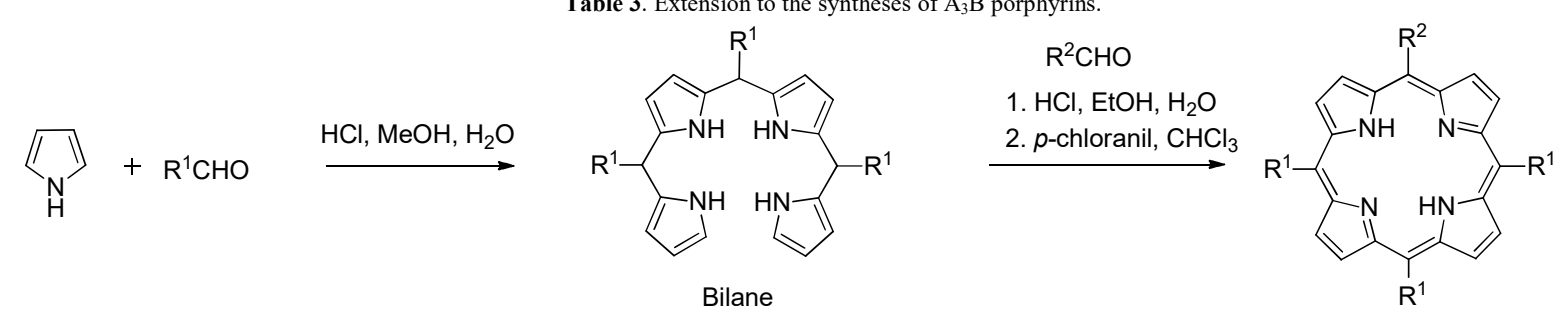

\begin{tabular}{|c|c|c|c|c|c|c|c|c|}
\hline Aldehyde 1 & $\mathrm{R}^{1}$ & Bilane & Yield & Aldehyde 2 & $\mathrm{R}^{2}$ & Porphyrin & Yield & Reference (Yield) \\
\hline 12 & & 13 & $10 \%$ & 3 & & 15 & $5 \%$ & [a] \\
\hline 3 & & 14 & $57 \%$ & 7 & & 16 & $17 \%$ & [41] $(9,5 \%)$ \\
\hline 3 & & 14 & $57 \%$ & 17 & & 18 & $13 \%$ & [42] $(17 \%)$ \\
\hline 3 & & 14 & $57 \%$ & 2 & & 19 & $26 \%$ & [a] \\
\hline
\end{tabular}

[a] new compound

Table 4. Extension to the syntheses of $\mathrm{AB}_{2} \mathrm{C}$ Porphyrins.

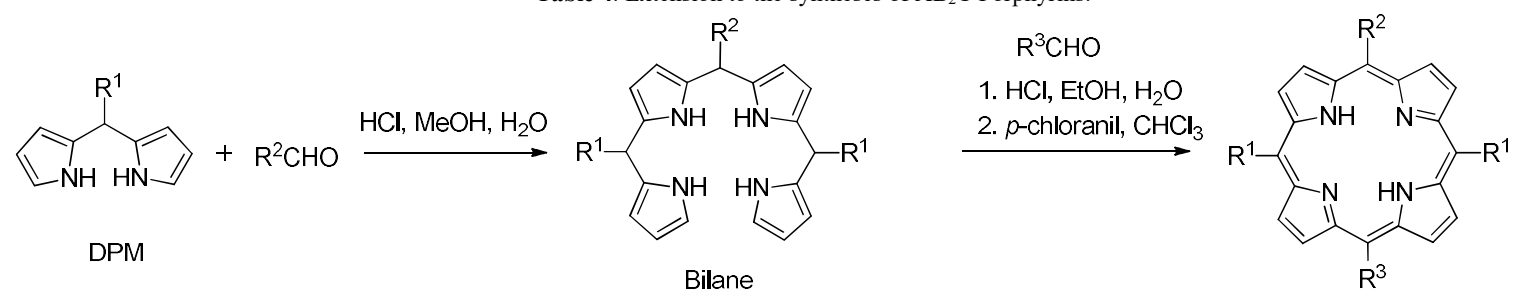

\begin{tabular}{|c|c|c|c|c|c|c|c|c|c|}
\hline DPM & $\mathrm{R}^{1}$ & Aldehyde 1 & $\mathrm{R}^{2}$ & Bilane & Yield & Aldehyde 2 & $\mathrm{R}^{3}$ & Porphyrin & Yield \\
\hline 1 & $\mathrm{H}$ & 12 & & 20 & $40 \%$ & 3 & & 22 & $15 \%$ \\
\hline 1 & $\mathrm{H}$ & 12 & & 20 & $40 \%$ & 2 & & 23 & $10 \%$ \\
\hline 6 & & 7 & & 21 & $63 \%$ & 3 & & 24 & $8 \%$ \\
\hline 6 & & 7 & & 21 & $63 \%$ & 2 & & 25 & $7 \%$ \\
\hline
\end{tabular}




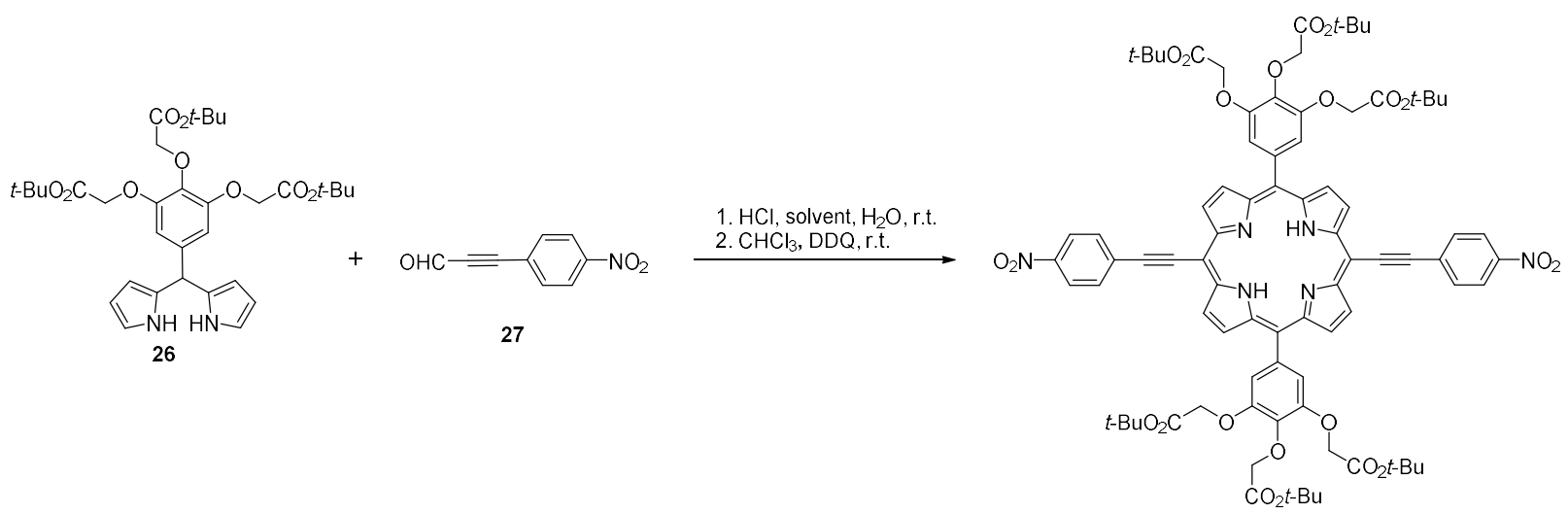

28

\begin{tabular}{|c|c|c|c|c|c|c|}
\hline Enry & Organic solvent $/ \mathrm{V}_{\mathrm{o}}^{[\mathrm{b}]}[\mathrm{mL}]$ & $\mathrm{V}_{\mathrm{w}}[\mathrm{mL}]^{[\mathrm{c}]}$ & $\mathrm{V}_{\mathrm{o}} / \mathrm{V}_{\mathrm{w}}{ }^{[\mathrm{d}]}$ & $\begin{array}{c}\mathrm{V}_{\mathrm{HCl}(\mathrm{aq})}[\mathrm{mL}] / \mathrm{n}_{\mathrm{HCl}} \\
{[\mathrm{mmol}]}\end{array}$ & $\mathrm{t}^{[\mathrm{d}]}[\mathrm{h}]$ & Yield $(\%)^{[\mathrm{e}]}$ \\
\hline 1 & $\mathrm{MeOH} / 14$ & 7 & $2: 1$ & $0.8 / 9.3$ & 3 & 5 \\
\hline 2 & $i-\mathrm{PrOH} / 14$ & 7 & $2: 1$ & $0.8 / 9.3$ & 3 & 10 \\
\hline 3 & $\mathrm{MeCN} / 14$ & 7 & $2: 1$ & $0.8 / 9.3$ & 3 & 16 \\
\hline 4 & $\mathrm{MeCN} / 10$ & 5 & $2: 1$ & $0.4 / 4.6$ & 3 & 12 \\
\hline 5 & THF/14 & 7 & $2: 1$ & $1.2 / 13.9$ & 3 & 14 \\
\hline 6 & THF/14 & 7 & $2: 1$ & $2.4 / 27.9$ & 3 & 9 \\
\hline 7 & THF/14 & 7 & $2: 1$ & $3.2 / 37.2$ & 3 & 8 \\
\hline 8 & THF/10 & 5 & $2: 1$ & $0.2 / 2.3$ & 3 & 25 \\
\hline 9 & THF/10 & 5 & $2: 1$ & $0.25 / 2.9$ & 3 & 20 \\
\hline 10 & THF/10 & 5 & $2: 1$ & $0.3 / 3.5$ & 3 & 20 \\
\hline 11 & THF/10 & 5 & $2: 1$ & $0.4 / 4.6$ & 3 & 18 \\
\hline 12 & THF/10 & 5 & $2: 1$ & $0.57 / 6.6$ & 3 & 18 \\
\hline 13 & THF/10 & 5 & $2: 1$ & $0.86 / 10.0$ & 3 & 16 \\
\hline 14 & THF/10 & 5 & $2: 1$ & $1.0 / 11.6$ & 3 & 15 \\
\hline 15 & THF/11.25 & 3.75 & $3: 1$ & $0.3 / 3.5$ & 3 & 21 \\
\hline 16 & THF/12 & 3 & $4: 1$ & $0.3 / 3.5$ & 3 & 24 \\
\hline 17 & THF/15 & 0 & - & $0.3 / 3.5$ & 3 & traces \\
\hline 18 & THF/12.5 & 6.25 & $2: 1$ & $0.375 / 4.4$ & 3 & 22 \\
\hline 19 & THF/7.5 & 3.75 & $2: 1$ & $0.175 / 2.0$ & 3 & 16 \\
\hline 20 & THF/7.5 & 3.75 & $2: 1$ & $0.225 / 2.6$ & 3 & 22 \\
\hline 21 & THF/7.5 & 3.75 & $2: 1$ & $0.3 / 3.5$ & 3 & 16 \\
\hline 22 & THF/12 & 3 & $4: 1$ & $0.3 / 3.5$ & 4.5 & 17 \\
\hline 23 & THF/14 & 7 & $2: 1$ & $0.28 / 3.3$ & 4.5 & 19 \\
\hline 24 & THF/14 & 7 & $2: 1$ & $0.8 / 9.3$ & 4.5 & 15 \\
\hline 25 & THF/16 & 4 & $4: 1$ & $0.25 / 2.9$ & 3 & 16 \\
\hline 26 & $\mathrm{THF} / 14$ & 7 & $2: 1$ & $0.4 / 4.6$ & 3.5 & 18 \\
\hline 27 & THF/11.25 & 3.75 & $3: 1$ & $0.2 / 2.3$ & 3.5 & 24 \\
\hline
\end{tabular}


Table 6. Synthesis of trans- $\mathrm{A}_{2} \mathrm{~B}_{2}$-porphyrins from arylpropynals and aryldipyrromethanes.
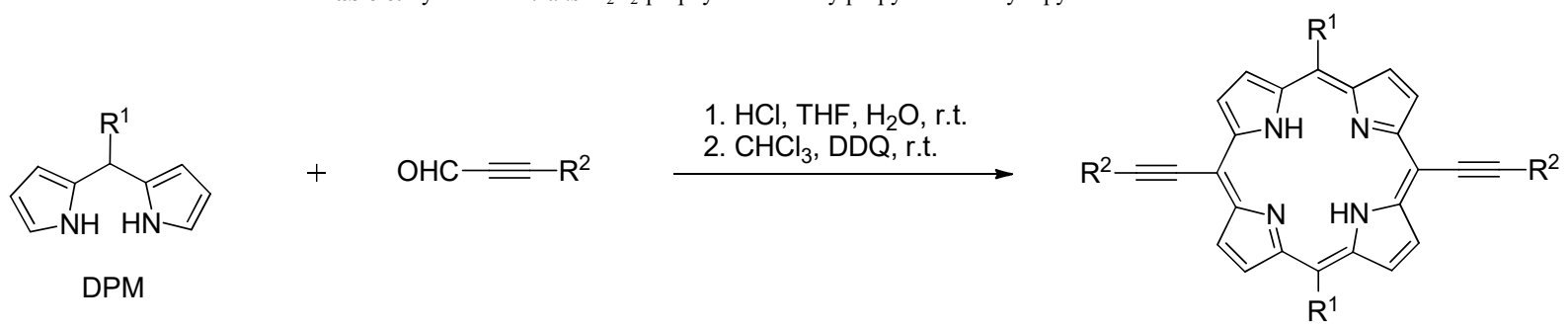

26


Table 7. Synthesis of $\mathrm{AB}_{2} \mathrm{C}$-porphyrins from bilanes and arylpropynals.

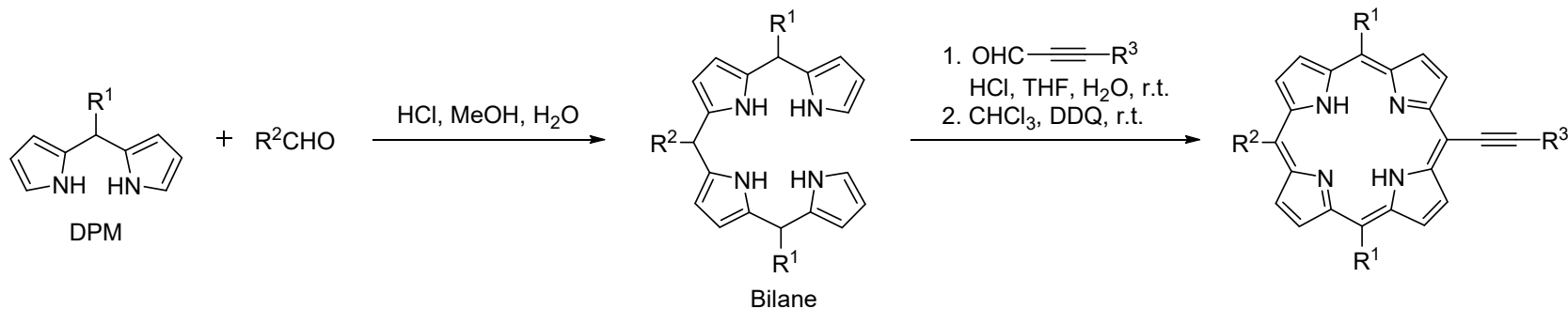

Bilane

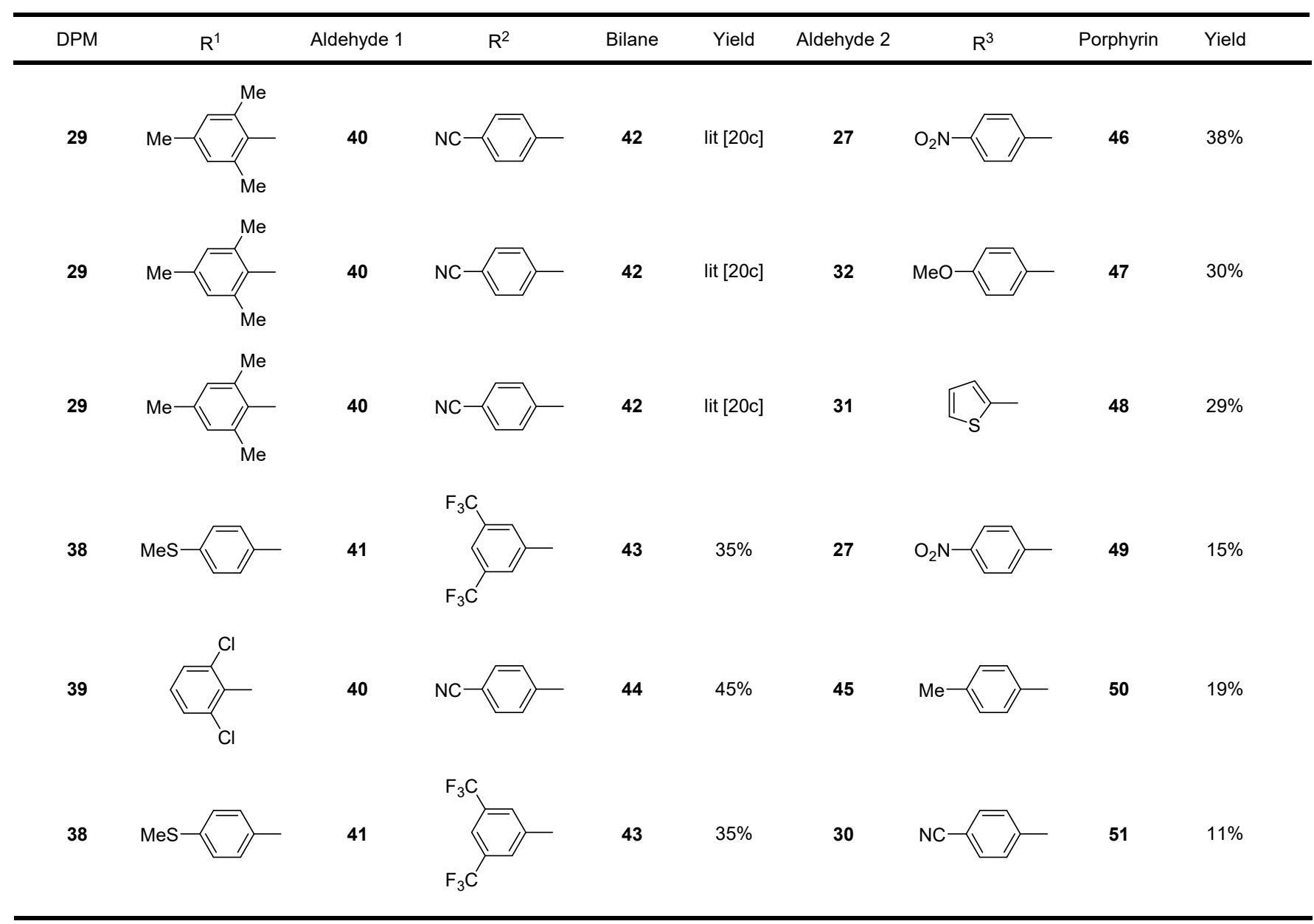



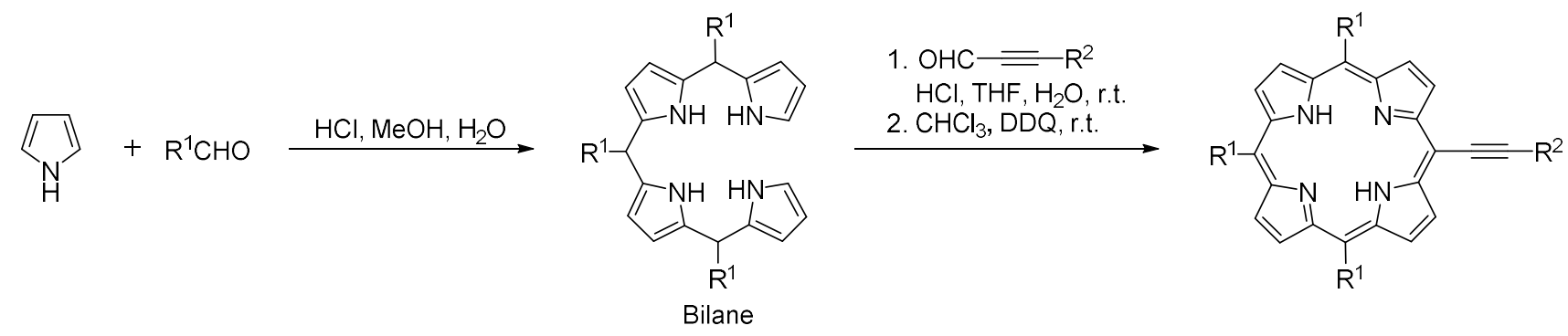

\begin{tabular}{|c|c|c|c|c|c|c|c|}
\hline Aldehyde 1 & $\mathrm{R}^{1}$ & Bilane & Yield & Aldehyde 2 & $\mathrm{R}^{2}$ & Porphyrin & Yield \\
\hline 40 & & 52 & lit [20c] & 33 & & 54 & $24 \%$ \\
\hline 7 & & 53 & $22 \%$ & 32 & & 56 & $16 \%$ \\
\hline
\end{tabular}

${ }^{a}$ Bilanes were obtained either from dipyrromethanes and aldehydes (a) or aldehydes and pyrrole (b). For (b) $\mathrm{R}^{1}=\mathrm{R}^{2}$.

\section{Conclusions}

This work establishes the foundation for an effective method to prepare trans- $\mathrm{A}_{2} \mathrm{~B}_{2}$-porphyrins, $\mathrm{A}_{3} \mathrm{~B}$-porphyrins and $\mathrm{AB}_{2} \mathrm{C}-$ porphyrins without scrambling in water-based media. The described methodology is diversity tolerant and offers good yields of porphyrins (9-25\%) for various types of dipyrromethanes including non-hindered 5-aryldipyrromethanes. In this last case the literature yields have been increased from $\sim 10 \%$ to $\sim 20 \%$. Our detailed study of the [2+2] condensation of dipyrromethanes and aldehydes led to the following conclusions: First, extensive changes in the reaction conditions make it possible to direct the cascade of Friedel-Crafts reactions between dipyrromethanes and aldehydes to form the porphyrinogen rather than bilane. Second, depending on the class of aldehydes (aromatic aldehydes vs. arylpropargyl aldehydes) the optimal co-solvent and acid concentration vary quite significantly. Third, regardless of the type of substituents (in terms of steric hindrance and/or electronic character) there is no scrambling in these reactions in spite of the relatively high concentration of protic acid (ca. $40 \mathrm{mM}$ or even $150 \mathrm{mM}$ for arylethynylporphyrin), which suggests that water plays a critical role in suppressing acid-catalyzed recombination.

A series of meso-substituted $\mathrm{A}_{3} \mathrm{~B}$-porphyrins were prepared in excellent yields using a $[3+1]$ strategy. Results leading to trans- $\mathrm{A}_{2} \mathrm{~B}_{2}-$ diaryl-bis(arylethynyl)porphyrins, provide a complementary method to two established alternative approaches leading to these types of $\pi$ extended porphyrins. The current methodology compares favorably with the existing procedures, especially for electron-deficient arylethynyl substituents where Sonogashira coupling of meso-bromoporphyrins with alkynes leads to inferior results. Reactions of bilanes with arylpropargyl aldehydes afforded porphyrins bearing one arylethynyl substituent, a missing link in the study of $\pi$-extended porphyrins, and these were isolated in 13-24\% yield. Overall, these studies have significantly extended our understanding of the acid-induced scrambling phenomenon and have increased our ability to prepare a potentially unlimited diversity of meso-substituted porphyrins bearing two or three different substituents in reasonable yields.

\section{Experimental Section}

Full experimental details are presented as Supporting Information.

${ }^{\dagger}$ These authors contributed equally to this work

\section{Acknowledgements}

In Marseille, we gratefully acknowledge funding from the EU-FP7 Future and Emerging Technologies Project PEPDIODE which prompted us to investigate novel methods for accessing functional porphyrinic constructs. In Warsaw, the authors thank the Polish National Science Centre (Contract No. UMO-2011/01/N/ST5/05633) and EUROCORES Programme EuroSolarFuels. 


\section{References}

[1] a) J. S. Lindsey, H. C. Hsu, I. C. Schreiman, Tetrahedron Lett. 1986, 27, 4969-4970. b) J. S. Lindsey, I. C. Schreiman, H. C. Hsu, P. C. Kearney, A. M. Marguerettraz, J. Org. Chem. 1987, 52, 827-836. c) J. S. Lindsey, R. W. Wagner, J. Org. Chem., 1989, 54, 828-836.

[2] a) The Porphyrin Handbook, K. M. Kadish, K. M. Smith, R. Guilard, Eds. Vols 1-20. b) Handbook of Porphyrin Science with Applications to Chemistry, Physics, Materials Science, Engineering, Biology and Medicine, K. M. Kadish, K. M. Smith, R. Guilard, Eds. World Scietific, 2010-2014, Vols. 1 - 35.

[3] a) T. S. Balaban, A. D. Bhise, M. Fischer, M. Linke-Schaetzel, C. Roussel, N. Vanthuyne, Angew. Chem. Int. Ed. 2003, 42, 2139-2144; Angew. Chem. 2003, 115, 2189-2194. (b) T. S. Balaban, R. Goddard, M. Linke-Schaetzel, J.-M. Lehn, J. Am. Chem. Soc. 2003, 125, 4233-4239.

[4] For some spectacular examples see J. A. Faiz, V. Heitz, J.-P. Sauvage, Chem. Soc. Rev. 2009, 38, $422-442$ and further references therein.

[5] a) A. D. Adler, F. R. Longo, W. Shergalis, J. Am. Chem. Soc. 1964, 86, 3145-3149. b) A. D. Adler, F. R. Longo, J. D. Finarelli, J. Goldmacher, J. Assour, L. Korsakoff, J. Org. Chem. 1967, 32, 476-476.

[6] (a) P. Rothemund, J. Am. Chem. Soc. 1935, 57, 2010-2011. (b) P. Rothemund, J. Am. Chem. Soc. 1936, 58, 625627. (c) P. Rothemund, J. Am. Chem. Soc. 1939, 61, 2912-2915. (d) P. Rothemund, A. R. Menotti, J. Am. Chem. Soc. 1941, 63, 267-270.

[7] G. P. Arsenault, E. Bullock, S. F. MacDonald, J. Am. Chem. Soc. 1960, 82, 4384-4389.

[8] B. M. Trost, Science, 1985, 227, 908-916.

[9] D. T. Gryko, D. Gryko, C.-H. Lee, Chem. Soc. Rev. 2012, 41, 3780-3789.

[10] B. J. Littler, Y. Ciringh, J. S. Lindsey, J. Org. Chem. 1999, 64, 2864-2872.

[11] a) F. Li, K. Yang, J. S. Tyhonas, K. A. MacCrum, J. S. Lindsey, Tetrahedron 1997, 53, 12339. b) G. A. Mirafzal, H. M. Bosse, J. M. Summer, Tetrahedron Lett. 1999, 40, 623-626. c) R. P. Bonar-Law, J. Org. Chem. 1996, 61, 3623-3634, d) B. F. O. Nascimento, M. Pineiro, A. M. d'A. Rocha Gonsalves, M. R. Silva, A. M. Beja, J. A. Paixão, J. Porphyrins Phthalocyanines 2007, 11, 77-84. e) H. Sharghi, A. H. Nejad, Helv. Chim Acta, 2003, 86, 408-414. f) R. Lucas, J. Vargnaud, K. Teste, R. Zerrouki, V. Sol, P. Krausz, Tetrahedron Lett. 2008, 49, 5537-5539.

[12] a) B. A. Freeman, K. M. Smith, Synth. Commun. 1999, 29, 1843-1855. b) G. R. Geier III, J. S. Lindsey, Org. Lett. 2000, 2, 1745-1748. c) G. R. Geier III, J. A. Riggs, J. S. Lindsey, J. Porphyrins Phthalocyanines 2001, 5, 681-690. d) R. Plamont, Y. Kikkawa, M. Takahashi, M. Kanesato, M. Giorgi, A. Chan Kam Shun, C. Roussel, T. S. Balaban, Chem. Eur. J. 2013, 19, 11293-11300.

[13] a) N. Jux Org. Lett. 2000, 2, 2129-2132. b) D. T. Gryko, M. Tasior, Tetrahedron Lett. 2003, 44, 3317-3320. c) S. H. H. Zaidi, R. M. Fico, Jr., J. S. Lindsey Org. Process Res. Dev. 2006, 10, 118-134. d) D. K. Dogutan, S. H. H. Zaidi, P. Thamyongkit, J. S. Lindsey J. Org. Chem. 2007, 72, 7701-7714. e) D. K. Dogutan, M. Ptaszek, J. S. Lindsey, J. Org. Chem. 2008, 73, 6187-6201. f) D. K. Dogutan, J. S. Lindsey J. Org. Chem. 2008, 73, 6728-6742. g) J. S. Lindsey, Acc. Chem. Res. 2010, 43, 300-311.

[14] J. S. Manka, D. S. Lawrence, Tetrahedron Lett. 1989, 30, 6989-6992.

[15] a) G. R. Geier III, B. J. Littler, J. S. Lindsey, J. Chem. Soc. Perkin Trans. 2, 2001, 701-711. b) D. T. Gryko, B. Koszarna, Synthesis, 2004, 2205-2209. c) M. Bröring, C. Milsmann, S. Ruck, S. Köhler, J. Organomet. Chem. 2009, 694, 1011-1015.

[16] (a) S. H. H. Zaidi, K. Muthukumaran, S.-I. Tamaru, J. S. Lindsey, J. Org. Chem., 2004, 69, 8356-8365. (b) S.-I. Tamaru, L. Yu, W. J. Youngblood, K. Muthukumaran, M. Taniguchi, J. S. Lindsey, J. Org. Chem., 2004, 69, 765-777. (c) D. S. Sharada, A. Z. Muresan, K. Muthukumaran, J. S. Lindsey, J. Org. Chem., 2005, 70, 3500 3510 .

[17] a) W. W. Kalish, M. O. Senge, Angew. Chem. Int. Ed. 1998, 37, 1107-1109. b) M. O. Senge, Acc. Chem. Res. 2005, 38, 733-743. c) M. O. Senge, Chem. Commun. 2011, 47, 1943-1960.

[18] a) M. O. Senge, Y. M. Shaker, M. Pintea, C. Ryppa, S. S. Hatscher, A. Ryan, Y. Sergeeva, Eur. J. Org. Chem. 2010, 237-258. b) X. D. Feng, M. O. Senge, J. Chem. Soc. Perkin Trans. 1, 2001, 1030-1038.

[19] Poster presentations at the $18^{\text {th }}$ European Symposium on Organic Chemistry in Marseille were performed on July $11^{\text {th }} 2013$.

[20] a) D. T. Gryko, K. Jadach, J. Org. Chem. 2001, 66, 599-602. b) R. Guilard, D. T. Gryko; G. Canard, J.-M. Barbe, B. Koszarna, S Brandès, M. Tasior, Eur. J. Org. Chem. 2002, 1735-1743. c) B. Koszarna, D. T. Gryko, J. Org. Chem. 2006, 71, 3707-3717.

[21] a) V. S.-Y. Lin, S. G. DiMagno, M. J. Therien, Science 1994, 264, 1105-1111. b) L. R. Milgrom, G. Yahioglu, Tetrahedron Lett. 1995, 36, 9061-9064. c) V. S.-Y. Lin, M. J. Therien, Chem. Eur. J. 1995, 1, 645-651. d) P. J. Angiolillo, V. S.-Y. Lin, J. M. Vanderkooi, M. J. Therien, J. Am. Chem. Soc. 1995, 117, 12514-12527. e) G. E. O'Keefe, G. J. Denton, E. J. Harvey, R. T. Philips, R. H. Friend, H. L. Anderson, J. Chem. Phys. 1996, 104, 805-811. f) S. M. LeCours, C. M. Philips, J. C. de Paula, M. J. Therien, J. Am. Chem. Soc. 1997, 119, 1257812589. g) S. M. LeCours, H.-W. Guan, S. G. DiMagno, C. H. Wang, M. J. Therien, J. Am. Chem. Soc. 1996, 118, 1497-1503.

[22] a) K. S. Kim, S. B. Noh, T. Katsuda, T. Ito, A. Osuka, D. Kim, Chem. Commun. 2007, 2479-2481. b) A. Krivokapic, A. R. Cowley, H.L. Anderson, J. Org. Chem. 2003, 68, 1089-1096. c) A. Krivokapic, H. L. 
Anderson, G. Bourhill, R. Ives, S. Clark, K. J. McEwan, Adv. Mater. 2001, 13, 652-656; d) K. J. McEwan, G. Bourhill, J. M. Robertson, H. L. Anderson, J. Nonlinear Opt. Phys. Mater. 2000, 9, 451-468.

[23] a) M. J. Plater, S. Aiken, G. Bourhill, Tetrahedron, 2002, 58, 2405-2413. b) H. L. Anderson, A. P. Wylie, K. Prout, J. Chem. Soc., Perkin Trans. 1 1998, 1607-1611.

[24] a) C.-W. Lee, H.-P. Lu, C.-M. Lan, Y.-L. Huang, Y.-R. Liang, W.-N. Yen, Y.-C. Liu, Y.-S. Lin, E. W.-G. Diau, C.-Y. Yeh, Chem. Eur. J. 2009, 15, 1403-1412. b) H. P. Lu, C.-L. Mai, C.-Y. Tsai, S.-J. Hsu, C.-P. Hsieh, C.-L. Chiu, C.-Y. Yeh, E. W.-G. Diau, Phys. Chem. Chem. Phys. 2009, 11, 10270-10274. c) H.-P. Lu, C.-Y. Tsai, W.-N. Yen, C.-P. Hsieh,C.-W. Lee, C.-Y. Yeh, E. W.-G. Diau, J. Phys. Chem. C, 2009, 113, 20990-20997. d) C.-F. Lo, S.-J. Hsu, C.-L. Wang, Y.-H. Cheng, H.-P. Lu, E. W.-G. Diau, C.-Y. Lin, J. Phys. Chem. C, 2010, 114, 12018-12023; e) C.-P. Hsieh, H.-P. Lu, C.-L. Chiu, C.-W. Lee, S.-H. Chuang, C.-L. Mai, W.-N. Yen, S.-J. Hsu, E. W.-G. Diau, C.-Y. Yeh, J. Mater. Chem. 2010, 20, 1127-1134. f) S.-L. Wu, H.-P. Lu, S.-H. Chuang, C.-L. Chiu, C.-W. Lee, E. W.-G. Diau, C.-Y. Yeh, Energy Environ. Sci. 2010, 3, 949-955. g) M. V. MartinezDiaz, G. de la Torre, T. Torres, Chem. Commun. 2010, 46, 7090-7108. h) For solar cells with a record breaking in power conversion efficiency assembled with a porphyrin having a meso-4-carboxyphenylethynyl substituent see: A. Yella, H.-W. Lee, H. N. Tsao, C. Yi, A. K. Chandiran, Md.K. Nazeeruddin, E. W.-G. Diau, C.-Y. Yeh, S. M. Zakeeruddin, M. Grätzel, Science, 2011, 334, 629-634.

[25] a) A. Nowak-Król, B. Koszarna, S. Y. Yoo; J. Chromiński, M. K. Węcławski, C.-H. Lee, D. T. Gryko, J. Org. Chem. 2011, 76, 2627-2634. b) A. Nowak-Król, C. J. Wilson, M. Drobizhev, D. V. Kondratuk, A. Rebane, H. L. Anderson, D. T. Gryko, ChemPhysChem, 2012, 13, 3966-3972. c) D. Koszelewski, A. Nowak-Król, M. Drobizhev, C. J. Wilson, J. E. Haley, T. M. Cooper, J. Romiszewski, E. Górecka, H. L. Anderson, A. Rebane, D. T. Gryko, J. Mat. Chem. C, 2013, 1, 2044-2053. d) A. Nowak-Król, M. Grzybowski, J. Romiszewski, M. Drobizhev, G. Wicks, M. Chotkowski, A. Rebane, E. Górecka, D. T. Gryko, Chem. Commun. 2013, 49, 83688370 .

[26] H. L. Anderson, Tetrahedron Lett. 1992, 33, 1101-1104.

[27] L. Karki, F. W. Vance, J. T. Hupp, S. M. LeCours, M. J. Therien, J. Am Chem. Soc. 1998, 120, $2606-2611$.

[28] S. M. LeCours, S. G. DiMagno, M. J. Therien, J. Am. Chem. Soc. 1996, 118, 11854-11864.

[29] a) P. N. Taylor, A. P. Wylie, J. Huuskonen, H. L. Anderson, Angew. Chem. Int. Ed. 1998, 37, 986-989. b) H. L.Anderson, Chem. Commun. 1999, 2323-2330. c) S. M. Kuebler, R. G. Denning, H. L. Anderson, J. Am. Chem. Soc. 2000, 122, 339-347. d) T. E. O. Screen, K. B. Lawton, G. S. Wilson, N. Dolney, R. Ispasoiu, T. Goodson, S. J. Martin, D. D. C. Bradley, H. L. Anderson, J. Mater. Chem. 2001, 11, 312-320.

[30] G. S. Wilson, H. L. Anderson, Synlett 1996, 1039-1040.

[31] D. Bonifazi, F. Diederich, B. Jaun, M. Scholl, P. Seiler, L. Echegoyen, A. Palkar, F. Song, G. Accorsi, N. Armaroli, Helvetica Chimica Act. 2005, 7, 1839 -1884.

[32] B. Habermeyer, C. P. Gros, M. El Ojaimi, J.-M. Barbe, A. Takai, S. Fukuzumi, Chem. Eur. J. 2011, 38, 1067010681.

[33] A. Nowak-Król, B. Koszarna, S. Y. Yoo, J. Chromiński, M. K. Węcławski, C.-H. Lee, D. T. Gryko, J. Org. Chem. 2011, 76, 2627-2634.

[34] Z. Liu, A. A. Yasseri, R. S. Loewe, A. B. Lysenko, V. L. Malinovskii, Q. Zhao, S. Surthi, Q. Li, V. Misra, J. S. Lindsey, D. F. Bocian, J. Org. Chem. 2004, 69, 5568-5577.

[35] a) M. O. Senge, X. Feng, Tetrahedron Lett. 1999, 40, 4165-4168. b) M. O. Senge, X. Feng, J. Chem. Soc. Perkin Trans. 1 2000, 3615-3621. c) A. Wiehe, Y. M. Shaker, J. C. Brandt, S. Mebs, M. O. Senge, Tetrahedron 2005, 61, 5535-5564.

[36] P. K. Goldberg, T. J. Pundsack, K. E. Splan, J. Phys. Chem. A, 2011, 115, 10452-10460.

[37] A. Nowak-Król, D. Gryko, D. T. Gryko, Chem. Asian J. 2010, 5, 904-909.

[38] A. Wiehe, Y.M. Shaker, J.C. Brandt, S. Mebs, M.O. Senge, Tetrahedron 2005, 23, 5535-5564.

[39] J. Riggs-Sauthier, B.-L. Deng, Z. Ren, W. Zhang, X. Gu, F. J. Duarte, WO2008/33444 A2, 2008

[40] M. Suzuki, A. Osuka, Org. Lett. 2003, 21, 3943-3946.

[41] J. Liu, Y. Li, C. Wang, H. Chen, Y. Chen, L. Mao, A. Xu, J. Chem. Res. 2011, 12, 698 -702.

[42] F. Fungo, L.A. Otero, L.Sereno, J.J. Silber, E.N. Durantini, J. Mater. Chem. 2000, 3, 645 - 650. 